\title{
Performance Analysis of a Fabricated Line Focusing Concentrated Solar Distillation System
}

\author{
Temoor Abbas Larik ${ }^{1}$, Abdul Qayoom Jakhrani2,,*, Abdul Rehman Jatoi ${ }^{3}$ and \\ Kishan Chand Mukwana ${ }^{3}$
}

\begin{abstract}
${ }^{1}$ Department of Mechanical Engineering, Quaid-e-Awam University College of Engineering, Science and Technology Larkano, Pakistan
${ }^{2}$ Department of Chemical Engineering, Quaid-e-Awam University of Engineering, Science and Technology Nawabshah, Pakistan

${ }^{3}$ Department of Energy and Environment Engineering, Quaid-e-Awam University of Engineering, Science and Technology Nawabshah, Pakistan
\end{abstract}

\begin{abstract}
A line focusing concentrated solar distillation unit was developed and its techno-economic analysis was carried out using batch flow, continuous flow without and with tracking mechanisms. Physical quality parameters of feed and distilled water samples, water temperature at different points, performance analysis and estimated production of developed unit were examined. The examined quality parameters of distilled water were well below permissible limits. The water temperature inside the concentrated tube was in the range of $107.0^{\circ} \mathrm{C}$ to $109.0^{\circ} \mathrm{C}$. The quantity of distilled water was observed to be inversely proportional to the amount of total dissolved solids in the water samples. The measured average daily and estimated lifetime yield from the developed unit during batch flow was 4.0 and 13,621.0 liters, for continuous flow without tracking 5.1 and 19,689.0 liters, and with tracking mechanism 5.7 and 21,758.0 liters, respectively. The continuous flow with tracking mechanism was found as best method for the production of distilled water. The total life cycle cost of the project was estimated to be PKR 62,144.00. The estimated unit cost of the distilled water per liter would be PKR 6.06 for continuous flow with tracking and PKR 9.69 for batch flow technique. C2019. CBIORE-IJRED. All rights reserved
\end{abstract}

Keywords: Line focusing concentrator, Performance analysis, Solar distillation, Water Treatment, Desalination

Article History: Received: Dec 24, 2018; Revised: April 14, 2019; Accepted: May 1, 2019; Available online: July 15, 2019

How to Cite This Article: Larik, T.A., Jakhrani, A.Q., Jatoi, A.R. and Mukwana, K.C (2019) Performance Analysis of a Fabricated Line Focusing Concentrated Solar Distillation System. International Journal of Renewable Energy Development, 8(2), $185-192$. https://doi.org/10.14710/ijred.8.2.185-192

\section{Introduction}

Water covers about $71 \%$ of the earth's surface. Seas and oceans contain approximately $96.5 \%$, groundwater $1.7 \%$, glaciers and ice caps $1.7 \%$, and the air as vapor $0.001 \%$ (Ajuonuma and Chukwudi, 2014). Only 2.5\% of the earth's water is fresh water. Just less than $1 \%$ of the total fresh water is accessible, which is mostly available in lakes, rivers and underground. The availability of potable water in arid regions of the world is a serious menace to the public. It is reported that about 1.1 billion people of the world have insufficient access to safe drinking water (Ajuonuma and Chukwudi, 2014; Jakhrani et al. 2012a; Jakhrani et al. 2012b; Mintz et al. 2001). Population increase, industrialization and urbanization are the main cause of increasing water demand. Easy access to hygienic and pure water is a fundamental for daily routine life. Its impact on health is impossible to ignore (Mintz et al. 2001; Gleick 1998; Jakhrani et al. 2009).

Water on the earth is being contaminated with impurities and chemical substances, which needs to be treated before consumption. An individual requires 20-50 liters/day of freshwater for drinking, cooking and cleaning. Since, more than one in six people worldwide (894 million) don't have access to the daily required quantity of freshwater. The drinking water requirement per person per day is 2 to 4 liters (Gleick 1998; Jakhrani et al. 2009). About 2.5 billion people live without basic sanitation, and approximately 1.5 million deaths occur each year globally due to unhygienic conditions (Gleick 1998; Jakhrani et al. 2009; Patil et al. 2002). Diarrhea is the leading cause of illness and death. Meanwhile, 85 percent of diarrhea deaths are due to a lack of access to sanitation facilities, together with inadequate availability of water for hygiene and unsafe drinking water (O'Ryan et al. 2005). World Health Organization (WHO) recommended that total dissolved solids (TDS) level in drinking (potable) water should be less than 600 $\mathrm{mg} / \mathrm{L}$ and increasingly unpalatable at TDS levels greater than $1000 \mathrm{mg} / \mathrm{L}$ (WHO, 2008).

Groundwater of Nawabshah city is mostly brackish and is not fit for human consumption without any treatment (Khuhawar and Majidano, 2011). Conventional treatment processes, like boiling,

\footnotetext{
* Corresponding author: aqunimas@hotmail.com
} 
chlorination and filtration are being used to clean the water from contaminants. These methods are usually expensive, remove less salt content and also have environmental complexities, and also require some external source of power for their operation (Boulestreau et al. 2012). Using solar energy for water treatment is become more common as the heat and energy from the sun can be captured and used for the treatment of brackish waters. Water distillation is one of possible alternative to remove salt content of any source water with the help of solar energy without any external source (Banat and Qiblawey, 2007). It is a low-cost technology and can easily be implemented anywhere in the world. This technology is practicable especially in those regions where the availability of fresh water is problematic and sunshine hours are long. However, their practicability and performance analysis are necessary for proper functioning and development of distillation units. Therefore, this study was conducted to develop a costeffective line focusing concentrated solar distillation unit for reducing the salts content of water.

\section{Materials and Methods}

\subsection{Water sampling}

The water samples were taken from four different locations of Nawabshah city, namely Taj Colony (TC), New Naka (NN), Ghareebabad (GA) and Essa Bhatti (EB). The water samples were collected on the basis of different concentrations of total dissolved salts in raw water. After sample collection, the samples were stored as per guidelines in a thermoset in order to maintain their temperature.

\subsection{Analysis of water quality}

A line focusing parabolic concentrating solar distillation unit of $13.7 \mathrm{ft}^{2}$ size was developed and its performance is evaluated. The level of $\mathrm{pH}$, electrical conductivity (EC) and total dissolved salts (TDS) of feed (brackish) water samples (FDW), and distilled (product) water samples were measured. Three different mechanisms, i.e., batch flow (DWB), continuous flow without tracking (DNT), and continuous flow with tracking (DWT) was adopted for analysis of feed and as well as distilled water samples. The results obtained from the developed unit were compared with World Health Organization (WHO) guideline values and United States Environmental Protection Agency (USEPA) standards. Ambient temperature, intensity of solar radiation, relative humidity and wind speed at the site was recorded on hourly basis from June to August 2016. All measurements were made from 09:00 to 17:00 hours. Inlet (feed) water before concentrator tube; outlet (distilled) water from the concentrator tube and temperature of condensed water was noted. $\mathrm{pH}$ of feed and distilled water was measured with Lovibond, PH110, electrical conductivity/total dissolved solids with HI98302, ELE International, HANNA, solar radiation with HD 2302, ambient temperature and relative humidity with thermo-hygrometer, KT 302, and wind speed with anemometer AVM-03. K-type thermocouple were used to measure the inlet water temperature $\left(\mathrm{T}_{\mathrm{i}}\right)$, outlet water temperature $\left(\mathrm{T}_{0}\right)$ and condenser temperature $\left(\mathrm{T}_{\mathrm{c}}\right)$ as shown in Fig. 1. Water temperature at different points on the installed unit was recorded with MS-6501 data logger. The effect of total dissolved salts content on the distilled water production rates (yield) was determined. Based on hourly distilled water production rates, the monthly and lifetime distilled water production values were estimated. The economic analysis of the installed distillation unit was carried out using life cycle cost method with net present value technique. The unit cost of distilled water was compared with other conventional desalination systems.

\section{Results and Discussions}

The results include the water quality parameters, climatic conditions, performance and economic evaluation of the developed unit. The water quality parameters comprised of $\mathrm{pH}$, electrical conductivity and total dissolved solids of feed and distilled water. The effect of climatic conditions, such as solar radiation, ambient temperature, relative humidity and wind speed on system performance was investigated with three different working mechanisms, namely, batch flow, continuous flow with and without tracking. The economical practicability of installed system was calculated using life cycle method with net present value cost analysis technique. The unit cost of distilled water was compared with other conventional distillation systems.

\subsection{Water quality analysis}

The results obtained after investigation of feed and distilled water obtained from different flow mechanisms are shown in Table 1. The level of $\mathrm{pH}$, electrical conductivity and total dissolved salts of feed water for Taj Colony were 7.59, $2450 \mu \mathrm{S} / \mathrm{cm}$ and $1568 \mathrm{mg} / \mathrm{L}$, New Naka 7.58, $2850 \mu \mathrm{S} / \mathrm{cm}$ and $1881 \mathrm{mg} / \mathrm{L}$, Ghareebabad 8.06, $2440 \mu \mathrm{S} / \mathrm{cm}$ and $1562 \mathrm{mg} / \mathrm{L}$, and Essa Bhatti were $8.40,1805 \mu \mathrm{S} / \mathrm{cm}$ and $1155 \mathrm{mg} / \mathrm{L}$ respectively. In batch flow techniques, the maximum value of $\mathrm{pH}$ in distilled water samples of New Naka with 7.02, and the lowest from Taj Colony with 6.95. The maximum values of EC and TDS in distilled water samples were noted from New Naka water samples with $20 \mu \mathrm{S} / \mathrm{cm}$, and $12 \mathrm{mg} / \mathrm{L}$, and minimum from Essa Bhatti with $14 \mu \mathrm{S} / \mathrm{cm}$, and $8 \mathrm{mg} / \mathrm{L}$ respectively. Moreover, in the continuous flow without tracking mechanism, the highest value of $\mathrm{pH}$ in distilled water samples was noted from Gharebabad water samples with 7.36, whereas the highest values of EC and TDS were found New Naka samples with $25 \mu \mathrm{S} / \mathrm{cm}$ and $16 \mathrm{mg} / \mathrm{L}$ respectively. The lowest values of $\mathrm{pH}$ were found in Taj Colony water samples with 7.1, the lowest EC and TDS from Gharebabad. Similarly, in continuous flow with tracking mechanism, the maximum $\mathrm{pH}$ was found in the distilled water samples from Essa Bhatti with 7.41, and TDS and EC from New Naka with 28 $\mu \mathrm{S} / \mathrm{cm}$ and $19 \mathrm{mg} / \mathrm{L}$ respectively. The lowest $\mathrm{pH}$ was found in Taj Colony water samples with 7.13, whereas, the lowest TDS and EC from Essa Bhatti location with $20 \mu \mathrm{S} / \mathrm{cm}$ and $13 \mathrm{mg} / \mathrm{L}$ respectively. The mean values of $\mathrm{pH}$, electrical conductivity and total dissolved salts of all examined distilled water samples for batch flow was 6.99, $17 \mu \mathrm{S} / \mathrm{cm}$ and $10 \mathrm{mg} / \mathrm{L}$, for continuous flow without tracking was $7.23,23 \mu \mathrm{S} / \mathrm{cm}$ and $14 \mathrm{mg} / \mathrm{L}$, and for 
continuous flow with tracking $7.25,26 \mu \mathrm{S} / \mathrm{cm}$ and 17 $\mathrm{mg} / \mathrm{L}$, respectively. It was discovered that the values of the quality parameters of distilled water were within WHO standards.

\subsection{Performance evaluation}

The performance of developed system was evaluated by measuring climatic conditions of the area and operational parameters. Four important climatic parameters considered were ambient temperature $\left(\mathrm{T}_{\mathrm{a}}\right)$, global solar radiation $\left(\mathrm{I}_{\mathrm{a}}\right)$, relative humidity $(\mathrm{RH})$ and wind speed $(\mathrm{V})$.

\subsubsection{Climatic conditions}

Climatic conditions of the site during study period are tabulated in Table 2 and Figs. 2 to 5. The mean and maximum ambient temperature during $\mathrm{BF}$ was $40.3^{\circ} \mathrm{C}$ and $43.1{ }^{\circ} \mathrm{C}$ at $16: 00$ hours and for the period of NT 39.8 ${ }^{\circ} \mathrm{C}$ and $41.9{ }^{\circ} \mathrm{C}$ at $14: 00$ hours and in WT $39.8^{\circ} \mathrm{C}$ and 42.3 ${ }^{\circ} \mathrm{C}$ at 1400 hours respectively as shown in Fig. 2. The mean and maximum global solar radiation during $\mathrm{BF}$ was $938 \mathrm{~W} / \mathrm{m}^{2}$ and $1071 \mathrm{~W} / \mathrm{m}^{2}$ at $13: 00$ hours and in the duration of NT $885 \mathrm{~W} / \mathrm{m}^{2}$ and $1028 \mathrm{~W} / \mathrm{m}^{2}$ at 13:00 hours and in WT $956 \mathrm{~W} / \mathrm{m}^{2}$ and $1077 \mathrm{~W} / \mathrm{m}^{2}$ at 13:00 hours respectively as shown in Fig. 3. The mean and maximum relative humidity during $\mathrm{BF}$ was $41 \%$ and $59 \%$ at 9:00 hours and in the duration of NT 54\% and 63\% at 9:00 hours and in WT $51 \%$ and $66 \%$ at 9:00 hours respectively as shown in Fig. 4.

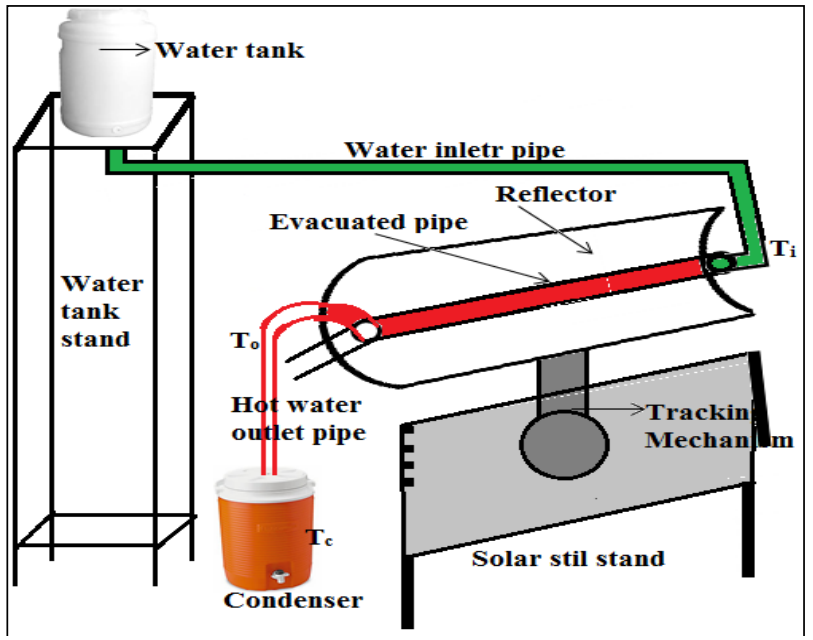

Fig. 1 Schematic diagram of solar distilled unit

The mean and maximum wind speed during BF was $1.49 \mathrm{~m} / \mathrm{s}$ and $3.05 \mathrm{~m} / \mathrm{s}$ at 17:00 hours and in the course of NT $1.26 \mathrm{~m} / \mathrm{s}$ and $2.06 \mathrm{~m} / \mathrm{s}$ at 16:00 hours and in WT 0.93 $\mathrm{m} / \mathrm{s}$ and $1.26 \mathrm{~m} / \mathrm{s}$ at 17:00 hours respectively as shown in Fig. 5. In general, the climate of the study area was warm and dry. The relative humidity was found inversely proportional to the ambient temperature.

\subsubsection{Temperature level at different points of developed unit}

The average temperature level at different points on the concentrator is shown in Table 3 and Figs 6 to 8 . The mean and maximum inlet temperature during $\mathrm{BF}$ was $44.3^{\circ} \mathrm{C}$ and $54.7^{\circ} \mathrm{C}$, for NT $44.2^{\circ} \mathrm{C}$ and $52.1^{\circ} \mathrm{C}$, and with WT $42.8^{\circ} \mathrm{C}$ and $53.5^{\circ} \mathrm{C}$ at $17: 00$ hours respectively. The mean and maximum outlet temperature during $\mathrm{BF}$ was $96.5^{\circ} \mathrm{C}$ and $107.0^{\circ} \mathrm{C}$ at $14: 00$ hours and for the period of NT $105.8^{\circ} \mathrm{C}$ and $108.8^{\circ} \mathrm{C}$ at $13: 00$ hours and in WT $105.9^{\circ} \mathrm{C}$ and $108.5^{\circ} \mathrm{C}$ at $14: 00$ hours respectively. The mean and maximum condensate temperature during $\mathrm{BF}$ was $49.2^{\circ} \mathrm{C}$ and $64.1^{\circ} \mathrm{C}$, for NT $52.1^{\circ} \mathrm{C}$ and $67.8^{\circ} \mathrm{C}$, and in WT $53.3^{\circ} \mathrm{C}$ and $69.4^{\circ} \mathrm{C}$ at $17: 00$ hours respectively.

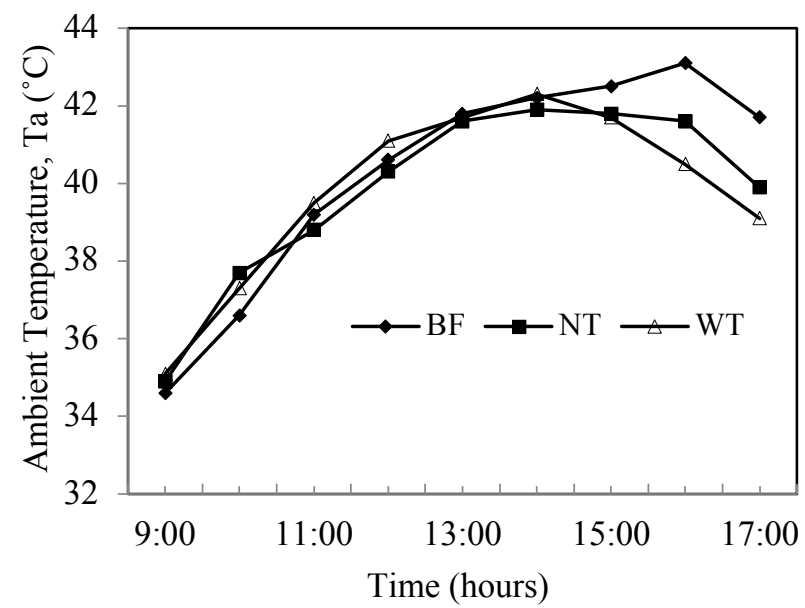

Fig. 2 Ambient temperature at the site during study period

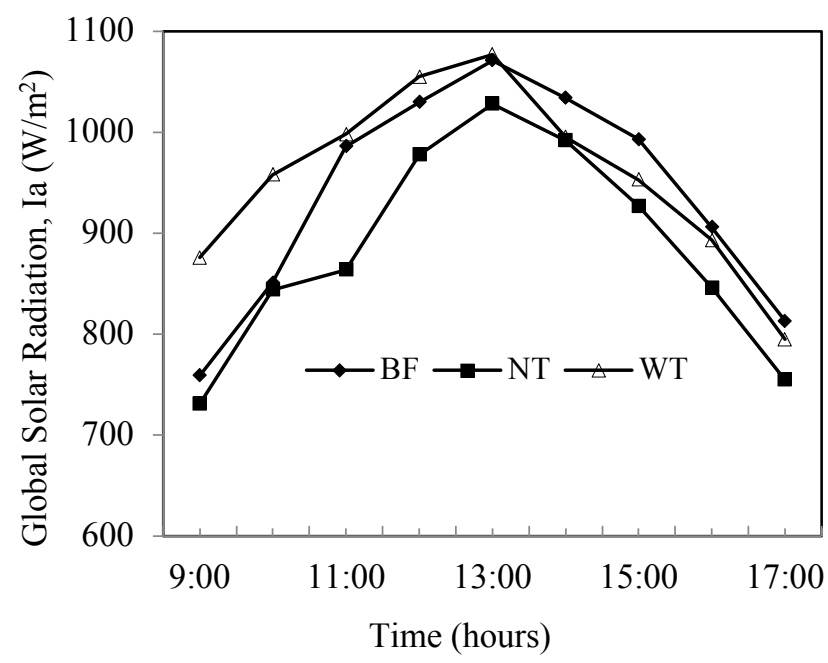

Fig. 3 Global solar radiation at the site during study period

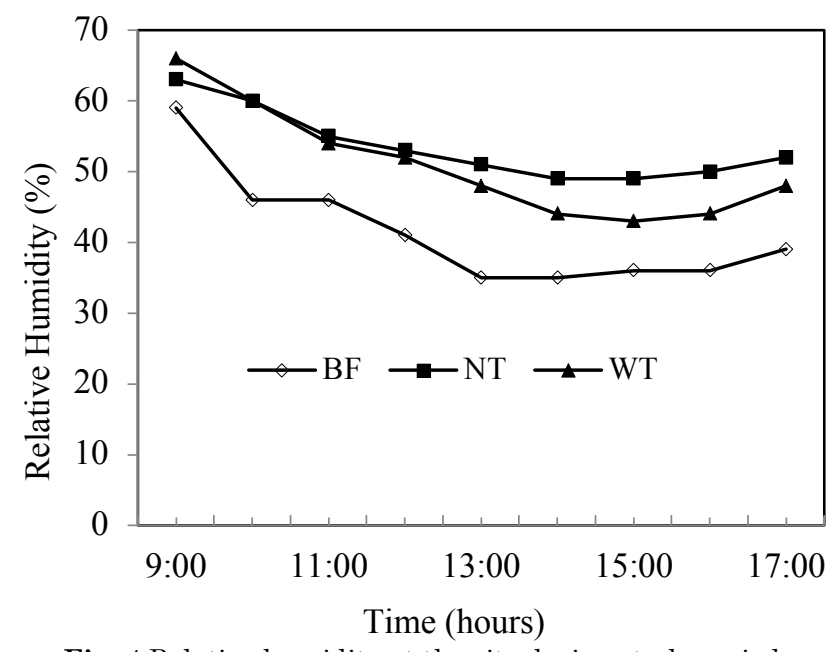

Fig. 4 Relative humidity at the site during study period 


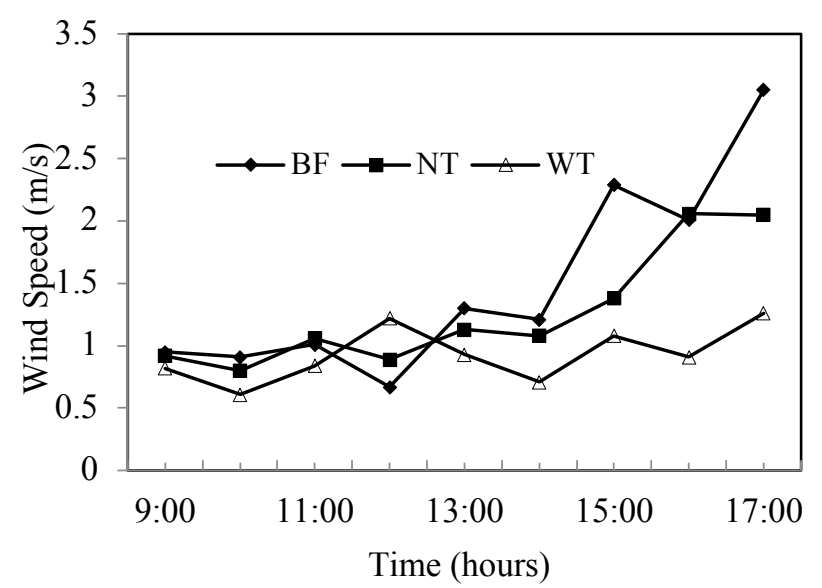

Fig. 5 Wind speed at the site during study period

\subsubsection{Average yield of developed unit}

The results of average hourly distilled water production from the installed unit during analysis period are given in Fig. 9. The minimum distilled water quantity during $\mathrm{BF}, \mathrm{NT}$ and WT techniques was obtained with $316 \mathrm{~mL} / \mathrm{h}, 413 \mathrm{~mL} / \mathrm{h}$ and $435 \mathrm{~mL} / \mathrm{h}$, and maximum $577 \mathrm{~mL} / \mathrm{h}, 891 \mathrm{~mL} / \mathrm{h}$ and $916 \mathrm{~mL} / \mathrm{h}$ respectively.

The daily average total distilled water production during BF, NT and WT was 4.0, 5.1 and 5.7 liters. The maximum yield in all flow conditions was noted at 14:00 hours and minimum at 10:00 hours.

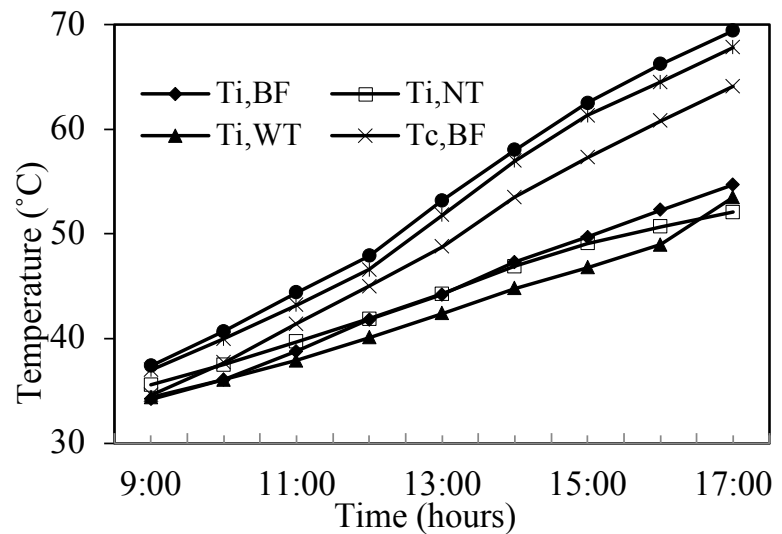

Fig. 6 Inlet water temperature, Ti and condensate temperature, $\mathrm{Tc}$ at different points on concentrator

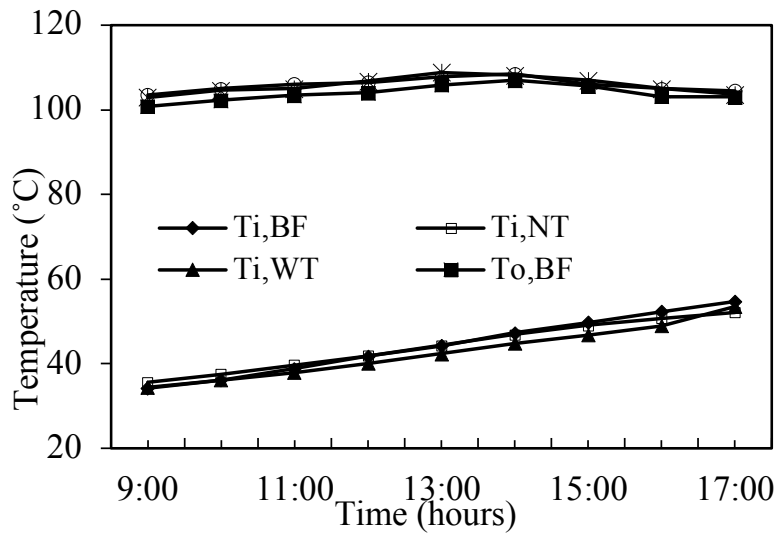

Fig. 7 Inlet water temperature, Ti and outlet temperature, Tc at different points on concentrator

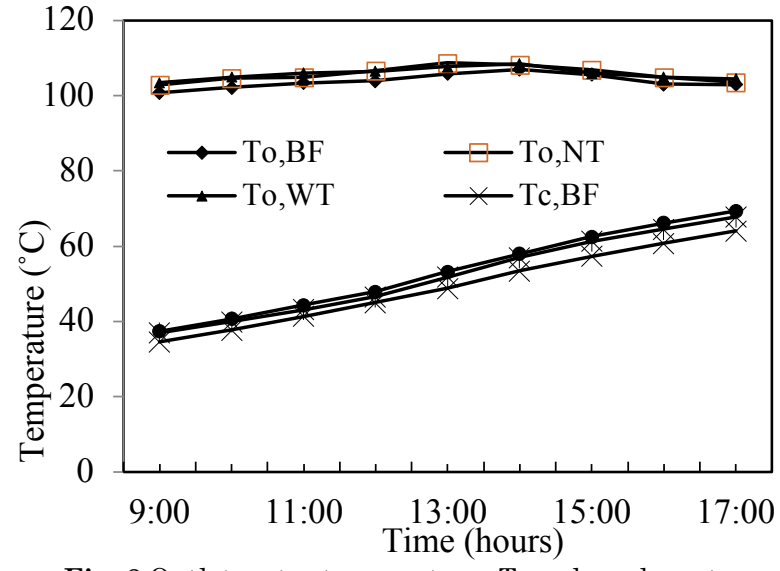

Fig. 8 Outlet water temperature, $\mathrm{T}_{\mathrm{o}}$ and condensate temperature, $\mathrm{T}_{\mathrm{c}}$ at different points on concentrator

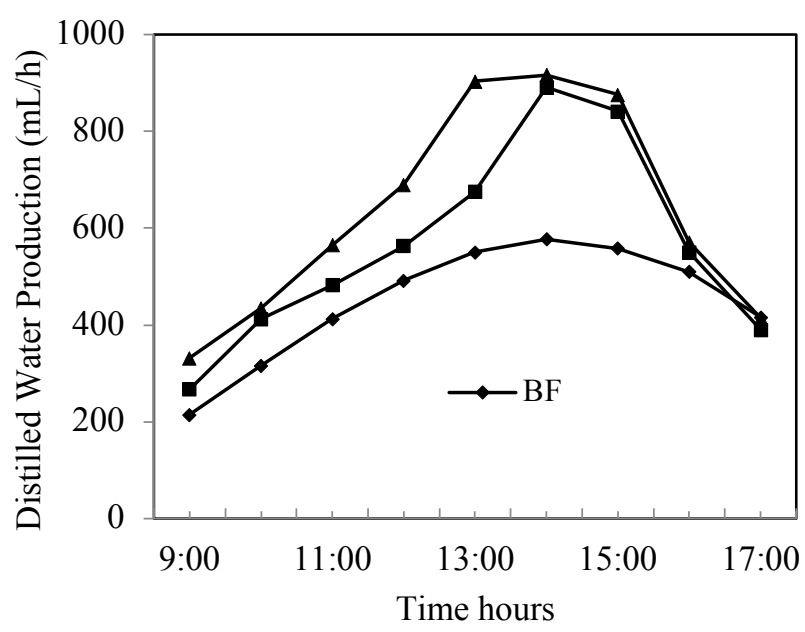

Fig. 9 Distilled water production in different flow conditions during study period

However, the distilled water production quantity was different due to application of different flow systems, tracking mechanism, and weather conditions. In early hours of the day, the yield was low and it was increased slightly and reaching up to maximum at the noon and again decreasing in the evening.

\subsubsection{Effect of total dissolved solids on water production}

The water samples taken from four different locations which contained different composition of total dissolved solid (TDS) and electrical conductivity (EC). When the amount of TDS was $1155 \mathrm{mg} / \mathrm{L}$, the production of distilled water was more with $4783 \mathrm{~mL}$, and when the TDS level was $1881 \mathrm{mg} / \mathrm{L}$, the yield was less with 4563 $\mathrm{mL}$ from the system as shown in Fig. 10. It was found from the analysis that the production of distilled water quantity was inversely proportional to the amount of TDS in the water samples.

\subsubsection{Quality of produced distilled water}

The output of distilled water for each day during all flow conditions were tested for $\mathrm{pH}$, electrical conductivity and total dissolved salts. The average $\mathrm{pH}$ of distilled water was found from 7.0 to 7.2 against the standard of 6.5 to 8.5 of both WHO and USEPA. The average values of EC were noted from $17.9 \mu \mathrm{S} / \mathrm{cm}$ to $25.4 \mu \mathrm{S} / \mathrm{cm}$. 
However, there is no standard value provided by both organizations. The average TDS of samples were 16.4 $\mathrm{mg} / \mathrm{L}$ to $107.7 \mathrm{mg} / \mathrm{L}$ against WHO standard of less than $1000 \mathrm{mg} / \mathrm{L}$ (WHO, 2008) and USEPA less than $500 \mathrm{mg} / \mathrm{L}$ (Nasrullah et al. 2006; DeZuane 1997). It was exposed from the results that all examined distilled water samples were within standards.

\subsection{Distilled water production}

The distilled water output is estimated for different months of a year using all flow techniques in the month of June, July and August. On the basis of NASA data, the rate of distilled water production was estimated for the different month of year as shown in Fig. 11. The estimated maximum output of distilled water for BF, NT and WT would be 114, 155 and 170 liters in the month of July and minimum in the month of January with 54, 77 and 100 liters respectively. The yearly production of the installed system could be 1043 liters in the application of BF, 1456 liters for NT, and 1665 liters with WT mechanism.

The total life span of the project was expected to be fifteen years as per literature review. It is projected that the system may lower the yearly production at the rate of $2 \%$ (Jakhrani et al. 2012d). At initial years, the system might produce maximum output and after the passage of time, its production may be decreased due to rusting, and other environmental factors. The lifetime estimated distilled water output from the installed system for all flow techniques is shown in Fig. 12. The total life time production of distilled water by application of $\mathrm{BF}$ would be 13,621 liters, with NT 19,689 liters and for WT mechanisms 21,758 liters.

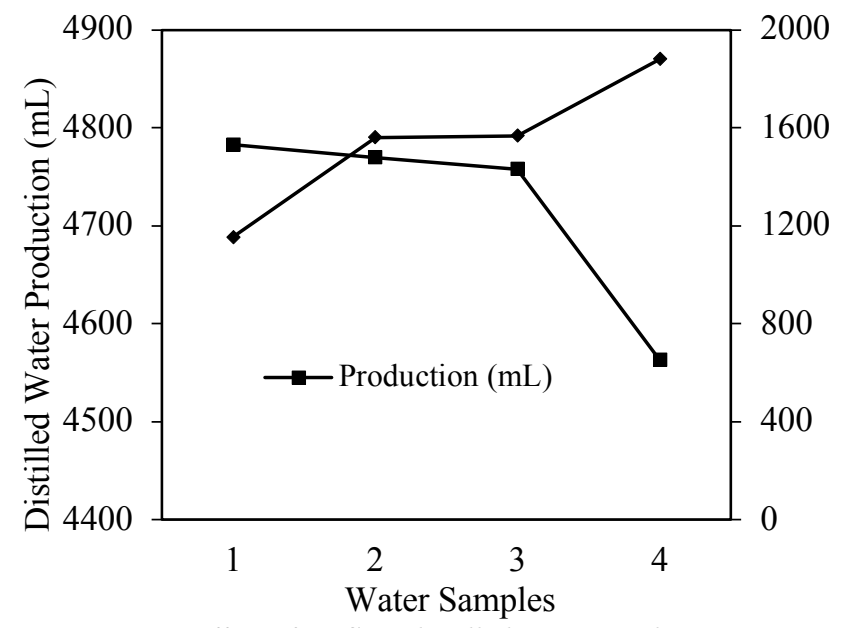

Fig. 10 Effect of TDS on distilled water production

\section{Economic Analysis of Developed Unit}

Economic analysis decides the systems attractiveness, as it measures the overall desirability of the project in financial terms and indicates the superiority of a single approach over the others that may be equally feasible in a technical perspective. The main economic elements necessary for the economic evaluation of the project life are inflation rate and discount (interest) rate (Jakhrani et al. 2012c). Inflation rate indicate the increase in cost, and discount rate is the rate of interest reflecting the investor's time value of money. The average inflation rate in Pakistan from year 2001 to 2014 was about 9.0\% (Global Economy, 2017).

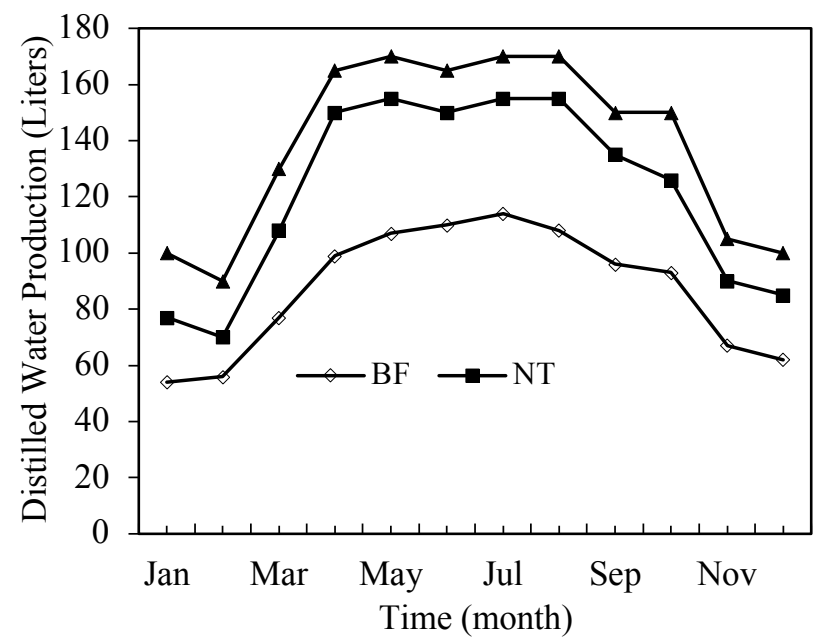

Fig. 11 Estimated monthly production from fabricated system in different flow techniques

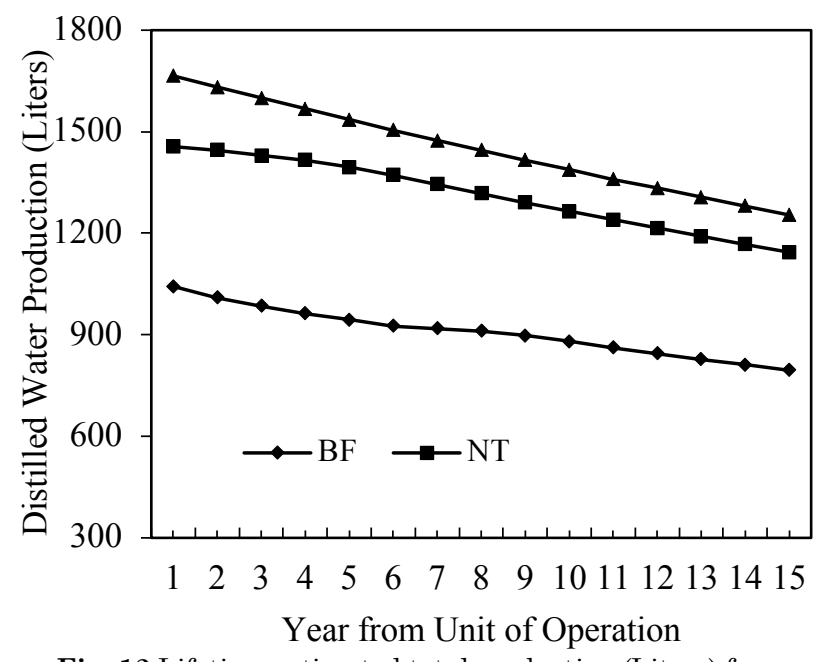

Fig. 12 Lifetime estimated total production (Liters) from installed system in different flow technique

The discount rate is fundamentally equal to amount of cash that could make the capital if it selected for an investment in any other financial organization. The average discount rate in Pakistan during year 1992-2015 was about 11.9\% (Trading Economics, 1992-2017). Moreover, the better economic return on the investment depends on the production cost of the distilled water and its applicability.

The total life cycle cost of the system includes its capital cost (purchasing of equipment, assembly cost, installation cost, transportation cost, and labor cost), operational and repair cost, replacement cost, disposal cost and salvage value (Jakhrani et al. 2012c). The total capital cost of components was estimated to be PKR 44,860.00, operation and maintenance cost PKR $13,873.00$, and the replacement cost of the components would be PKR 3,411.00. Hence, the total life cycle cost in Pakistani Rupees (PKR) of the project was found to be PKR 62,144.00 with a salvage value of PKR 1204.00. Thus, the net total life cycle cost of the project became PKR 60,940.00. It was found that the expensive part of the developed unit would be glass concentrator with PKR $11,000.00$ and labor cost PKR 10,000.00. 
Citation: Larik, T.A., Jakhrani, A.Q., Jatoi, A.R. and Mukwana, K.C (2019) Performance Analysis of A Fabricated Line Focusing Concentrated Solar Distillation System. Int. Journal of Renewable Energy Development, 8(2), 185-192, doi.org/ijred.8.2.185-192

P a g e 190

Table 1

Results of quality parameters of feed and distilled water samples

\begin{tabular}{|c|c|c|c|c|c|c|c|c|c|c|c|c|}
\hline \multirow{2}{*}{ Location } & \multicolumn{4}{|c|}{$\mathbf{p H}$} & \multicolumn{4}{|c|}{$\mathrm{EC}(\mu \mathrm{S} / \mathrm{cm})$} & \multicolumn{4}{|c|}{ TDS (mg/L ) } \\
\hline & FDW & DWB & DNT & DWT & FDW & DWB & DNT & DWT & FDW & DWB & DNT & DWT \\
\hline $\mathrm{TC}$ & 7.59 & 6.95 & 7.10 & 7.13 & 2450 & 18 & 24 & 28 & 1568 & 11 & 15 & 18 \\
\hline NN & 7.58 & 7.02 & 7.22 & 7.20 & 2850 & 20 & 25 & 28 & 1881 & 12 & 16 & 19 \\
\hline GA & 8.06 & 6.98 & 7.36 & 7.24 & 2440 & 15 & 19 & 26 & 1562 & 9 & 12 & 16 \\
\hline Mean & 7.91 & 6.99 & 7.23 & 7.25 & 2386 & 17 & 23 & 26 & 1542 & 10 & 14 & 17 \\
\hline
\end{tabular}

Table 2

Average weather cnditions during study period

\begin{tabular}{|c|c|c|c|c|c|c|c|c|c|c|c|c|c|c|c|c|}
\hline \multirow{3}{*}{ Time } & \multicolumn{4}{|c|}{ Ambient Temp. } & \multicolumn{4}{|c|}{ Solar Radiation } & \multicolumn{4}{|c|}{ Relative Humidity } & \multicolumn{4}{|c|}{ Wind Speed } \\
\hline & \multicolumn{4}{|c|}{$\mathrm{Ta}\left({ }^{\circ} \mathrm{C}\right)$} & \multicolumn{4}{|c|}{ Ia $\left(W / m^{2}\right)$} & \multicolumn{4}{|c|}{ RH (\%) } & \multicolumn{4}{|c|}{$\mathrm{V}(\mathrm{m} / \mathrm{sec})$} \\
\hline & $\mathrm{BF}$ & NT & WT & Mean & $\mathrm{BF}$ & NT & WT & Mean & $\mathrm{BF}$ & NT & WT & Mean & $\mathrm{BF}$ & NT & WT & Mean \\
\hline 9:00 & 34.6 & 34.9 & 35.1 & 34.9 & 759 & 731 & 876 & 789 & 59 & 63 & 66 & 63 & 0.95 & 0.92 & 0.82 & 0.90 \\
\hline $10: 00$ & 36.6 & 37.7 & 37.3 & 37.2 & 851 & 844 & 958 & 884 & 46 & 60 & 60 & 55 & 0.91 & 0.80 & 0.61 & 0.77 \\
\hline $11: 00$ & 39.2 & 38.8 & 39.5 & 39.2 & 986 & 864 & 998 & 949 & 46 & 55 & 54 & 52 & 1.01 & 1.06 & 0.84 & 0.97 \\
\hline $12: 00$ & 40.6 & 40.3 & 41.1 & 40.7 & 1,030 & 978 & 1,055 & 1,021 & 41 & 53 & 52 & 49 & 0.67 & 0.89 & 1.22 & 0.93 \\
\hline $13: 00$ & 41.8 & 41.6 & 41.7 & 41.7 & 1,071 & 1,028 & 1,077 & 1,059 & 35 & 51 & 48 & 45 & 1.30 & 1.13 & 0.93 & 1.12 \\
\hline $14: 00$ & 42.2 & 41.9 & 42.3 & 42.1 & 1,034 & 992 & 995 & 1,007 & 35 & 49 & 44 & 43 & 1.21 & 1.08 & 0.71 & 1.00 \\
\hline $15: 00$ & 42.5 & 41.8 & 41.7 & 42.0 & 993 & 927 & 953 & 958 & 36 & 49 & 43 & 43 & 2.29 & 1.38 & 1.08 & 1.58 \\
\hline $16: 00$ & 43.1 & 41.6 & 40.5 & 41.7 & 906 & 846 & 893 & 882 & 36 & 50 & 44 & 43 & 2.01 & 2.06 & 0.91 & 1.66 \\
\hline $17: 00$ & 41.7 & 39.9 & 39.1 & 40.2 & 813 & 755 & 795 & 788 & 39 & 52 & 48 & 46 & 3.05 & 2.05 & 1.26 & 2.12 \\
\hline
\end{tabular}

$\mathrm{BF}=$ Batch flow, $\mathrm{NT}=$ Without tracking, WT= With tracking

Table 3

Average water temperatures at different points on the developed desalination unit

\begin{tabular}{|c|c|c|c|c|c|c|c|c|c|c|c|c|}
\hline \multirow{3}{*}{ Time } & \multicolumn{4}{|c|}{ Water Temperature at Inlet } & \multicolumn{4}{|c|}{ Water Temperature at Outlet } & \multicolumn{4}{|c|}{ Water Temperature at Condenser } \\
\hline & \multicolumn{4}{|c|}{$\mathrm{Ti}\left({ }^{\circ} \mathrm{C}\right)$} & \multicolumn{4}{|c|}{ To $\left({ }^{\circ} \mathrm{C}\right)$} & \multicolumn{4}{|c|}{$\operatorname{Tc}\left({ }^{\circ} \mathrm{C}\right)$} \\
\hline & $\mathrm{BF}$ & NT & WT & Mean & $\mathrm{BF}$ & NT & WT & Mean & $\mathrm{BF}$ & NT & WT & Mean \\
\hline 9:00 & 34.2 & 35.6 & 34.4 & 34.7 & 34.6 & 102.9 & 103.5 & 80.3 & 34.6 & 37.0 & 37.4 & 36.3 \\
\hline $10: 00$ & 36.1 & 37.5 & 36.1 & 36.6 & 102.2 & 104.6 & 105.0 & 103.9 & 37.7 & 40.0 & 40.7 & 39.5 \\
\hline $11: 00$ & 38.8 & 39.7 & 37.9 & 38.8 & 103.4 & 105.0 & 106.1 & 104.8 & 41.4 & 43.2 & 44.4 & 43.0 \\
\hline $12: 00$ & 41.8 & 41.9 & 40.1 & 41.3 & 104.0 & 106.8 & 106.5 & 105.8 & 45.0 & 46.6 & 47.9 & 46.5 \\
\hline $13: 00$ & 44.2 & 44.3 & 42.4 & 43.6 & 105.9 & 108.8 & 107.8 & 107.5 & 48.8 & 51.8 & 53.2 & 51.3 \\
\hline $14: 00$ & 47.3 & 46.9 & 44.8 & 46.3 & 107.0 & 108.2 & 108.5 & 107.9 & 53.5 & 57.0 & 58.0 & 56.2 \\
\hline $15: 00$ & 49.7 & 49.1 & 46.8 & 48.5 & 105.6 & 107.0 & 106.0 & 106.2 & 57.3 & 61.3 & 62.5 & 60.4 \\
\hline $16: 00$ & 52.3 & 50.7 & 49.0 & 50.7 & 103.1 & 105.0 & 105.0 & 104.4 & 60.8 & 64.5 & 66.2 & 63.8 \\
\hline $17: 00$ & 54.7 & 52.1 & 53.5 & 53.4 & 103.0 & 103.6 & 104.5 & 103.7 & 64.1 & 67.8 & 69.4 & 67.1 \\
\hline Mean & 44.3 & 44.2 & 42.8 & 43.8 & 96.5 & 105.8 & 105.9 & 102.7 & 49.2 & 52.1 & 53.3 & 51.6 \\
\hline
\end{tabular}

\subsection{Annuity and unit cost of distilled water}

The interest factor annuity of the developed unit was found to be 6.93. Annuity is the fixed amount of cash, required to be paid in each year, usually for the rest of the project life. Annuity was determined by dividing interest factor annuity, 6.93. The unit cost of distilled water was obtained by dividing the average distilled water production per year by annuity. The total life time production of distilled water by the application of $\mathrm{BF}$, NT, and WT mechanisms were 13,621 liters, 19,689 liters and 21,758 liters respectively. The lowest price of the distilled water per liter was estimated to be PKR 6.06 for continuous flow with tracking, PKR 6.70 for continuous flow without tracking, and PKR 9.69 for batch flow technique. The highest unit cost of distilled water was 
estimated from batch flow, and the lowest from continuous flow with tracking mechanism.

\subsection{Cost comparison with other studies}

The total capital cost and unit cost of distilled water (PKR/liter) of the developed system is compared with conventional types of solar distillation systems. The highest capital cost of such units was found from the work of (Badran and Al-Tahaineh, 2005) with PKR 50,400.00 and cost of distilled water per liter was PKR 12.08. The lowest project cost was reported from the work of (Samee et al. 2007) with PKR 20,140.00, and the lowest unit cost of pure water was reported by (EL-Sebaii et al. 2008) with PKR 5.46. The net capital cost of the developed unit was estimated to be PKR 44,860.00 with the unit cost of PKR 6.06.

\section{Conclusions}

A line concentrated solar distillation unit is developed and its performance is analyzed. The groundwater samples were collected from four different locations. These samples were preserved in cans as per standards and brought to the laboratory for treatment and analysis. The weather was found warm and dry. The maximum outlet temperature during all flow conditions were in the range between $107.0^{\circ} \mathrm{C}$ to $109.0^{\circ} \mathrm{C}$. The quantity of distilled water production was found inversely proportional to the amount of total dissolved solids in the water samples. All examined distilled water samples after treatment were found within WHO standards. The total estimated life cycle cost of the project was PKR $62,144.00$, and the total estimated distilled water production with tracking mechanism was 21,758 liters. The lowest price of the distilled water per liter was estimated to be PKR 6.06 for continuous flow with tracking and the highest PKR 9.69 for batch flow technique. The unit cost of developed system was found to be comparable with literature quoted results.

\section{References}

Ajuonuma, U.P. \& Chukwudi, B.C. (2014) Design and construction of de-totle water treatment plant using moringa oleifera as bio-coagulant. The Pacific Journal of Science and Technology, 15(1), 1-12.

Badran, O.O. \& Al-Tahaineh, H. A. (2005) The effect of coupling a flat-plate collector on the solar still productivity. Desalination, 183(1-3), 137-142.

Banat, F. \& Qiblawey, H. (2007) Membrane desalination driven by solar energy, Solar desalination for the 21st century. A Review of Modern Technologies and Researches on Desalination Coupled to Renewable Energies, 271-291.

Boulestreau, M., Hoa, E., Peter-Verbanets, M., Pronk, W., Rajagopaul, R. \& Lesjean, B. (2012) Operation of gravitydriven ultrafiltration prototype for decentralized water supply. Desalination and water treatment, 42(1-3), 125-130.
DeZuane, J. (1997) Handbook of drinking water quality. John Wiley \& Sons

El-Sebaii, A.A., Ramadan, M.R.I., Aboul-Enein, S. \& Salem, N. (2008) Thermal performance of a single-basin solar still integrated with a shallow solar pond. Energy Conversion and Management, 49(10), 2839-2848.

Gleick, P.H. (1998) Water in crisis: paths to sustainable water use. Ecological Applications, 8(3), 571-579.

Jakhrani, A.Q. Samo, S.R. \& Nizamani, I. (2009) Impact of wastewater effluents on physico-chemical properties of groundwater. Sindh University Research Journal, 41(1), 7582.

Jakhrani, A.Q., Othman, A.K., Rigit, A.R.H., Samo, S.R., Ling, L.P. \& Baini, R. (2012d) Cost estimation of a standalone photovoltaic power system in remote areas of Sarawak, Malaysia. NED University Journal of Research, 15-25.

Jakhrani, A.Q., Rigit, A.R.H., Othman, A.K., Samo, S.R. \& Kamboh, S.A. (2012c) Life cycle cost analysis of a standalone PV system. In International Conference on Green and Ubiquitous Technology (GUT), IEEE, 82-85.

Jakhrani, A.Q., Samo, S.R., Siyal, Z.A., Sobuz, H.R., Uddin, M.A. \& Hasan, N.M.S. (2012a) Evaluation of dissolved salts and heavy metals in groundwater. International Journal of Structural and Civil Engineering, 1(2), 54-60.

Jakhrani, A.Q., Samo, S.R., Sobuz, H.R., Uddin, M.A., Ahsan, M.J. \& Hasan, N. M. S. (2012b) Assessment of dissolved salts concentration of seawater in the vicinity of Karachi. International Journal of Structural and Civil Engineering, 1(2), 61-69.

Khuhawar, M.Y. \& Majidano, S. A. (2011) An investigation of quality of groundwater of taluka Nawabshah. Pakistan Journal of Chemistry, 1(2), 65-71.

Mintz, E., Bartram, J., Lochery, P. \& Wegelin, M. (2001) Not just a drop in the bucket: expanding access to point-of-use water treatment systems. American Journal of Public Health, 91(10), 1565-1570.

Nasrullah, R.N., Bibi, H., Iqbal, M. \& Durrani, M.I. (2006) Pollution load in industrial effluent and ground water of Gadoon Amazai Induatrial Estate (GAIE) Swabi, NWFP. Journal of Agricultural and Biological Science, 1(3), 18-24.

O'Ryan, M., Prado, V. \& Pickering, L.K. (2005) A millennium update on pediatric diarrheal illness in the developing world. In Seminars in pediatric infectious diseases, 16(2), 125-136.

Patil, A.V., Somasundaram, K.V. \& Goyal, R.C. (2002) Current health scenario in rural India. Australian Journal of Rural Health, 10(2), 129-135.

Perré, P. (2004) Electrical heating of green logs using Joule's effect: a comprehensive computational model used to find a suitable electrode design. Wood Science and Technology, 38(6), 429-449.

Samee, M.A., Mirza, U.K., Majeed, T. \& Ahmad, N. (2007) Design and performance of a simple single basin solar still. Renewable and Sustainable Energy Reviews, 11(3), 543-549.

The Global Economy, Inflation: percent change in the Consumer Price Index.

http://www.theglobaleconomy.com/Pakistan/Inflation/, accessed on 02.11 .2017

Trading Economics, Pakistan interest rate 1992-2017.

https://tradingeconomics.com/pakistan/interest-rate, accessed on 02.11.2017.

World Health Organization (WHO), (2008) Guidelines for drinking-water quality. 3rd Edition, Incorporating first and second addenda, Recommendations, 1, 1-668.

http://www.who.int/water_sanitation_health/dwq/fulltext.pdf accessed 11. 11. 2017. 
Citation: Larik, T.A., Jakhrani, A.Q., Jatoi, A.R. and Mukwana, K.C (2019) Performance Analysis of A Fabricated Line Focusing Concentrated Solar Distillation System. Int. Journal of Renewable Energy Development, 8(2), 185-192, doi.org/ijred.8.2.185-192

$\mathrm{P}$ a g e $\mid 192$

(C) 2019. This article is an open access article distributed under the terms and conditions of the Creative Commons Attribution (CC BY) license (http://creativecommons.org/licenses/by/4.0/). 